\title{
Evaluating cultural industries: investigating visitors' satisfaction in theatres
}

\author{
Sabine Boerner*, Volker Moser and Johanna Jobst
}

Department of Politics and Management, University of Konstanz, Konstanz, Germany

\begin{abstract}
This study investigates visitors' satisfaction with their subjective experience in theatres. Reconciling research on theatre marketing and theatre studies, a model of visitors' satisfaction in theatre is suggested and an instrument to capture visitors' satisfaction and its determinants is developed. Results from a field study $(n=158)$ on three performances of 'Twelfth Night or What You Will' (Shakespeare) in a German community theatre revealed spectators' perception of stage direction and their emotional response as significant determinants. Comparing experienced to inexperienced visitors' judgements, no differences were found. Conclusions for theatre marketing are drawn.
\end{abstract}

Keywords: visitors' satisfaction in theatre; subjective judgements; experienced theatregoers; inter-rater agreement

\section{Introduction}

Given growing economic constraints, efforts towards customer orientation are increasingly considered to be necessary for theatrical organizations (Gilhespy, 1999; Scollen, 2008; Tobias, 2004; Voss \& Voss, 2000). Although seemingly to be at odds with theatres' artistic mission and creativity at first glance (Auvinen, 2001; DiMaggio, 1987; Eikhof \& Haunschild, 2007), reinforcing customer orientation may help theatres to better fulfil their artistic mission in the long run through a resulting rise in attendance levels and the fulfilment of economic goals. However, even a considerable increase in customer orientation should never aim to simply please and confirm superficial customer preferences and wishes. 'There is a real danger that this approach will lead to the production of safe, consumer-oriented art products which, in the end, may not be what the audience either wants or needs' (Caust, 2003, p. 58). Empirical evidence for the benefits of a rise in customer orientation is though mixed. Voss and Voss (2000) did not find a positive relationship between market orientation and theatre performance, whereas Gainer and Padanyi (2002) discovered a positive relation between theatres' market orientation and customer satisfaction, peer/artistic reputation, and resource attraction (for a theoretical argumentation see Caust, 2003).

Nevertheless, scholars in the field of marketing in the performing arts mostly agree in their claim to intensify customer orientation instead of product orientation (Gainer \& Padanyi, 2002; Kotler \& Scheff, 1997; Parasuraman, Zeithaml, \& Berry, 1988; Rentschler, Radbourne, Carr, \& Rickard, 2002; Scheff \& Kotler, 1996; Shoham, Ruvio, VigodaGadot, \& Schwabsky, 2006). Following Kotler and Scheff (1997, p. 34), customer 
orientation 'requires that the organization systematically study customers' needs and wants, perceptions and attitudes, preferences and satisfaction'. Similarly, Rentschler et al. (2002, p. 122) argued, 'the more the organization learns about and monitors the patrons' needs, preferences, attitudes and concerns, the more their satisfaction and commitment levels grow'. Modern marketing ideology thus contends that artists or arts organizations cannot really understand their product until they understand how the consumer or audience perceives it (March \& Thompson, 1996).

In particular, customer satisfaction has been identified as antecedent of both customers' behavioural intentions and their actual behaviour (e.g. Cronin, Brady, \& Hult, 2000; Cronin \& Taylor, 1992; Seiders, Voss, Grewal, \& Godfrey, 2005; Zeithaml, Parasuraman, \& Berry, 1996). However, while the services marketing literature has provided a broad range of general satisfaction measures (e.g. Wirtz \& Lee, 2003), research on customer satisfaction in theatrical organizations is still scarce (Scollen, 2008). Moreover, focusing on the antecedents of theatre attendance, existing empirical audience research in theatres has been restricted to collecting traditional demographic data (DiMaggio, 1987; Kotler \& Scheff, 1997; Sargeant, 1997; Senior, 2004). However, the effects of theatre attendance on spectators have scarcely been analysed. Empirical studies on customers' experience in theatre were predominantly focused on what Kotler and Scheff (1997, p. 192) have defined as the 'expected product' (e.g. ticket purchase, box office personal) or the 'augmented product' (e.g. discount at nearby restaurants, pre- or post-performance lecturers). Though, spectators' experience with a theatre's core product, i.e. the performance itself (Kotler \& Scheff, 1997, p. 192), has only recently been studied. Spectators' response to a theatre performance was investigated by Bourgeon, who discovered perceptions of quality (production, acting, the play, the message), perceptions of the ambience as well as emotions to be determinants of theatregoers' satisfaction (as cited in Kotler \& Scheff, 1997, p. 190 et seq.). Garbarino and Johnson (2001) identified selected plays, actors, theatre facilities, and theatre locations as determinants of attenders' overall satisfaction with a theatrical event. In their attempt to identify sex differences in customer satisfaction with a theatre's current season as a whole, ticket prices, and the current performance, Voss and Cova (2006) investigated audience perceptions of the technical quality (i.e. the quality of the core service) as well as the functional quality (i.e. the manner in which the service is delivered) offered by theatres. In the context of audience development, Scollen (2008) invited non-attenders to participate in a performance and analysed their experiences. In sum, although frequently called for, in the field of theatre marketing, systematic knowledge on visitors' satisfaction with a theatrical event is still limited.

In addition to the marketing literature, insights on visitors' experience in the theatre might be gained from the perspective of theatre studies. In this discipline, several studies on reception research have been published. The most pertinent one has been conducted by Sauter, Kalvik, and Isaksson (1986), who suggested an instrument to cover the elements (e.g. topic of the play, ensemble, music, stage design) which spectators perceive during a performance. Moreover, Sauter identified four segments of the theatrical event: playing culture, cultural context, cultural theatricality, and theatrical playing (Martin \& Sauter, 1995; Sauter, 2000, 2002). Likewise, Eversmann (2004) discovered four dimensions of visitors' experience of the theatrical event (i.e. perceptive, cognitive, emotional, and communicative dimension). Studies by Konijn (1991), Schoenmakers and Tulloch (2004), and Zillmann (1995) focused on spectators' emotions during a performance. In addition, visitors' perception of single components of the theatrical event has been investigated independently. Perky (1976) suggested a scale for the assessment of performers' quality which has been further elaborated by Konijn (1991). In the context of education, 
Pavis (1988) developed criteria for a semiotic expert analysis of theatrical performances (e.g. light, stage set).

In summary, neither the marketing literature nor theatre studies have provided a consistent framework conceptualizing the determinants of customer satisfaction in theatre. The aim of this paper is to close this gap by explaining visitors' satisfaction in the theatre. Reconciling the literature in theatre marketing and theatre studies, we suggest a (first) model specifying possible determinants of visitors' satisfaction. This model is tested in an empirical study, interviewing 158 attendees of Shakespeare's Twelfth Night or What You Will performed at a professional German community theatre. In this empirical study, the following research questions are addressed: (1) What are the determinants of visitors' satisfaction with a theatrical event? (2) Does visitors' satisfaction with an event differ according to their level of experience? Since customers' involvement and expectations are considered to be relevant for their experience in the performing arts, first-time theatregoers may respond differently to a production than frequent attendees (Kotler \& Scheff, 1997). Implications for theatre marketing are developed.

\section{Determinants of visitors' satisfaction with a theatrical event}

In the services marketing literature, different attempts have been made to conceptualize customer satisfaction. Although, traditionally, it has been conceptualized as a disconfirmation process (e.g. Grönroos, 1984; Lewis \& Booms, 1983; Parasuraman et al., 1988), recently an increasing number of researchers has achieved good predictive power by asking for customer's level of fulfilment (Dabholkar, Shepherd, \& Thorpe, 2000). In line with Oliver's (1996) suggestion, we therefore define customer satisfaction in the theatre as the spectator's judgement that the theatrical event provided a pleasurable level of consumption-related fulfilment, including levels of under- or over-fulfilment.

Approaches to marketing in the performing arts (e.g. Kotler \& Scheff, 1997; Rentschler et al., 2002; Schwerdtfeger, 2004; Voss \& Cova, 2006) agree in the distinction between the main service on the one hand, and the additional service(s) on the other hand. We thus assume that visitors' satisfaction with a theatrical event is likely to result from their perceptions of both main service and additional service.

In order to further specify the main service, we build on insights from theatre studies to identify important theatre-based qualities. In their attempt to comprise and systemize the elements that students mentioned in essays describing their experiences in theatre performances, Sauter et al. (1986) developed an instrument covering the following elements: (1) elements referring to the fiction of the performance (story, topic of play, parts), (2) elements of the stage direction and of performing (e.g. rhythm of the performance, voice, facial expression, the ensemble as a whole, the principle performer's style of shaping the part), (3) elements of the stage design and the costumes, and (4) elements of the music (if appearing). Following this approach, we design the main service in theatre to be composed of (1) the topic of the play, (2) stage direction, (3) the ensemble, (4) the principal performer, (5) stage design, and (6) music.

In order to specify the additional service provided by the theatre, we tried to identify characteristics of the service experience. Building on the literature (Garbarino \& Johnson, 2001; Schwerdtfeger, 2004; Voss \& Cova, 2006), we suggest that service quality comprises the infrastructure and the service delivered by the theatre.

In addition, in line with both the theatre marketing literature (e.g. Bourgeon as cited in Kotler \& Scheff, 1997) and theatre studies (e.g. Eversmann, 2004; Schoenmakers, 1988, 1992), we consider spectators' emotional response to the performance to be a decisive 


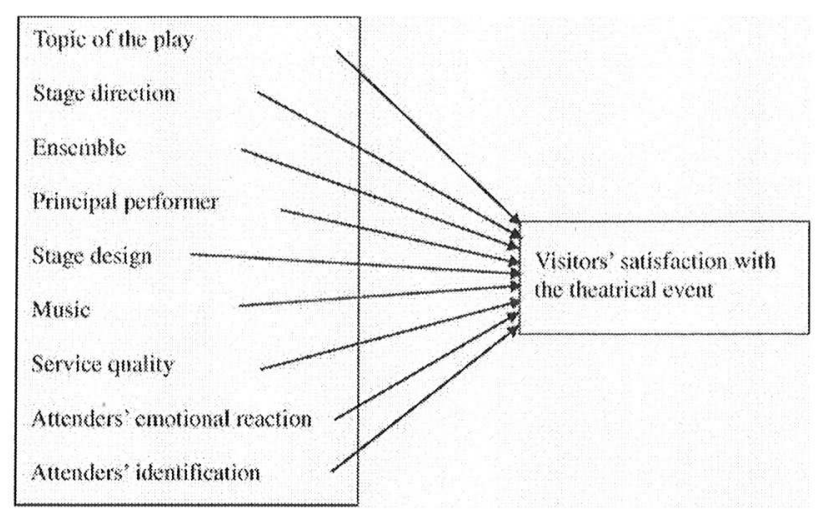

Figure 1. Determinants of visitors' satisfaction with the theatrical event.

determinant of their satisfaction. Approaches to reception research in theatre studies agree that emotions have a considerable impact on spectators' judgement on a theatrical performance (Andringa, 2004; Konijn, 1991, 1999; Schoenmakers, 1988, 1992; Tan, 1996; Zillmann, 1991). However, they disagree on the type of attenders' emotional response to a performance (i.e. identification, empathy, task emotions, contingent responses) and on the triggers of these emotional responses (e.g. performers, staging, author). Moreover, they do not provide a convincing suggestion to measure spectators' emotional response to a theatre performance.

Since the type of emotions aroused during the performance may depend on both the attenders' personality and the features of the performance under consideration (Eversmann, 2004), we decided to distinguish between the intensity of spectator's emotions referring to the performance as a whole (Tan, 1994) and his or her identification with the principal performer (cf. Konijn, 1991; Schoenmakers \& Tulloch, 2004).

To sum up, our model includes the following determinants of visitors' satisfaction with a theatrical event (Figure 1), (1) the topic of the play, (2) stage direction, (3) the ensemble, (4) the principal performer, (5) stage design (including costumes, requisites, and lighting), (6) music, (7) the service quality (infrastructure and service) provided by the theatre, (8) attenders' emotional reaction, and (9) attenders' identification with principal performer.

\section{The impact of experience on visitors' satisfaction}

According to DiMaggio, Useem, and Brown (1978, p. 5), 'a major question of audience research is whether there is one audience or many, and whether distinctions can be made according to audience types and their responsiveness to questions such as price and program content'. Since customers' involvement and expectations are considered to be relevant for their satisfaction with performing art events (Kotler \& Scheff, 1997; Parasuraman et al., 1988; Voss \& Cova, 2006), visitors may differ in their reactions to a theatrical event, resulting in different judgements on the same event. Kotler and Scheff (1997) identify a wide range of factors which may influence consumer behaviour in the performing arts, i.e. macro-environmental trends, cultural factors, social factors, psychological factors, and personal factors. In particular, they assume that 'a first-time operagoer will respond far differently to a production of La Bohème than will someone 
who has seen it five times' (Kotler \& Scheff, 1997, p. 195). However, the authors did not specify in which respect frequent attenders' reactions will differ from inexperienced spectators' reactions. Recent studies on reception research in opera have revealed only minor differences between frequent and occasional attenders (Boerner \& Jobst, 2008; Boerner, Neuhoff, Renz, \& Moser, 2008; Boerner \& Renz, 2008; Jobst, 2007). In the field of theatre, no effort has been made to analyse differences between experienced and less experienced visitors' perception of a theatrical event.

Applying the assumption of a cultural hierarchy of quality evaluation in the arts (e.g. Bourdieu, 1993; for a review, see Holbrook, 1999, 2005) to the field of theatre reception, differences between experts' and non-experts' perceptions and assessments of a theatrical event are to be expected. Experts differ from non-experts concerning their stocks of cultural capital (Bourdieu, 1993) like, for example, different experiences or different previous consumptions. Due to their connoisseurship, experts establish and apply certain standards when making their judgements (Holbrook, 1999). In other words, they know what is considered 'good' according to the criteria sanctioned by their cultural field. Non-experts - or ordinary consumers - apply the standards of popular appeal instead of the professional standards of evaluation (Holbrook, Lacher, \& La Tour, 2006).

Empirical evidence in various cultural fields indicates only weak positive associations between experienced and inexperienced judgements (cf. Holbrook, 2005; Holbrook et al., 2006). For example, critics' ratings of theatre performances have been found to differ significantly from those of laypersons (Boorsma \& van Maanen, 2003). Senior (2004) assumes experience to be the main reason for this difference: 'Critics would appear to believe that they can judge what real theatregoers will enjoy, ignoring that they themselves are far from being real theatregoers. They go to three or four productions a week, whereas an "average theatregoer" makes eight visits a year' (Senior, 2004, p. 65).

Differences between experienced and less experienced visitors' satisfaction with a theatrical event may occur in three forms. First, experienced attenders will make more rigorous judgements than inexperienced attenders. Due to their background, experienced listeners to concerts are assumed to develop higher expectation levels and thus to engage in more deliberate, critical evaluations than less experienced listeners (Boorsma \& van Maanen, 2003; Thompson, 2006). Applying this reasoning to judgements of theatrical events, we expect experienced visitors to be less satisfied with a theatrical event - i.e. their overall satisfaction and its determinants - than inexperienced visitors.

Second, frequent attenders may differ from occasional attenders in the relative importance they give to the individual determinants of their satisfaction. Due to their experience, frequent attenders may develop routines to handle the complex experience of a theatrical event (cf. Berlyne, 1971; Eversmann, 2004). The professional standards these attenders apply in their judgements may help to formulate an exhaustive and well-balanced consideration of all relevant aspects of the event. Occasional attenders, however, lacking both experience in theatres and professional standards for evaluation, are likely to suffer from sensual overload (Eversmann, 2004). As a result, they may become increasingly selective (Broadbent, 1964), focusing their attention on some aspects of the theatrical event (e.g. the principal performer) to which they give high relevance in their overall judgements while neglecting other aspects. Moreover, occasional attenders may have difficulties in assessing one or the other aspect (e.g. stage direction), resulting in lower weight given to this aspect in their overall judgements.

Applying Adorno's (1962) typology of listeners to music to spectators in theatre, we assume that frequent attenders are likely to emphasize aspects related to the play itself (i.e. stage direction, the topic of the play, stage design, the ensemble, the principal 
performer), whereas occasional attenders are expected to emphasize their personal resonance (i.e. emotional reaction, identification with principal performer) and the service quality (i.e. infrastructure and service). Bourgeon (as cited in Kotler \& Scheff, 1997, p. 191) found that, in general, the play itself is the main determinant of a frequent attender's feelings about the performance. But for occasional attenders, other intangible and atmospheric factors are more important'. Similarly, reception research in opera suggests that experts differ from non-experts in the emphasis given to the individual aspects of the event (Jobst, 2007).

Third, according to Bourdieu's (1993) cultural hierarchy, agreement in spectators' judgements on a theatrical event may be higher among experienced visitors than among inexperienced visitors. Experienced visitors, following established standards, may engage in a process of 'orchestration' of shared views and judgements (Boorsma \& van Maanen, 2003). Thus, inexperienced visitors will mainly consider their personal taste (or perhaps the views within their social circle), whereas experienced visitors 'write and judge in the context of a field of professional colleagues' (Boorsma \& van Maanen, 2003, p. 327). For the latter, therefore, both the basis of their judgements - the selection and weighting of quality criteria - and their expectation levels will be assimilated, which can lead to more homogeneous judgements among experienced visitors than among inexperienced visitors.

However, on the other hand, inexperienced visitors are likely to be more susceptible than experienced visitors to homogenizing processes working in the audience. During a live event in theatre, individual judgements may be influenced by a common mood or climate (Joyce \& Slocum, 1990) within the audience or by interaction processes among spectators. As Eversmann (2004) found, spectators can be influenced by emotions of others in that their feelings may be intensified and reinforced by the reactions of their neighbours. Moreover, group conformity (Asch, 1956) has been found to influence aesthetic judgements in general (Crozier, 1996). Group conformity may thus induce spectators to make dependent quality assessments, modifying their individual positions according to the majority opinion. Interactions among members of the auditorium, sometimes explicitly manifested in laughter, 'boos' or 'bravos', may thus have a harmonizing effect on quality evaluation, resulting in what Boorsma and van Maanen (2003, p. 329) called 'collective perceptions'. Occasional attenders, being less experienced in evaluating theatre performances, may thus be influenced by processes of social interaction in the audience, resulting in homogenizing their judgements more than frequent attenders' judgements (Behne, 1997; Crozier, 1996).

In sum, it is an open question whether experienced attenders' subjective judgements of a theatrical event will differ from inexperienced attenders' judgements in the degree of interpersonal agreement. On the one hand, in theatre management and cultural politics, experts' judgements are highly valued for their assumed 'objectivity' and frequently applied for decisions on resource allocation (Abbé-Decarroux, 1994; Glejser \& Heyndels, 2001; List, 1997; Senior, 2004). On the other hand, however, empirical studies found no agreement among professional theatre critics (Boerner, 2002; Senior, 2004).

\section{Method}

Sample

This study was carried out during three consecutive live performances of Twelfth Night or What You Will at the professional German community theatre of Konstanz in June 2007. To encourage spectators to participate, a poster was displayed in the foyer to call attention 
to the survey. With the assistance of the theatre's service personnel, questionnaires were distributed randomly among audience members and were handed to them directly. The return rates were $17 \%$ (Friday), 19\% (Saturday), and 25\% (Sunday), respectively. Over all the three performances, the respondents $(n=158)$ were predominately female $(61 \%)$ with an average age of 55 years $(\mathrm{SD}=14)$.

\section{Measures}

In order to operationalize the determinants of spectators' satisfaction with their subjective experience of a theatrical event, we developed scales for every construct included in our model (Figure 1). These scales were developed in three steps. First, to discover elements of the performance and of theatregoing that might not have been covered in Sauter et al.'s (1986) instrument, we conducted semi-structured interviews with theatregoers (two professionals, four frequent attenders, and two occasional attenders acquired after two performances of Ibsen's Hedda Gabler at the professional theatre Schaubühne in Berlin). The respondents confirmed the predominant role of emotions for their satisfaction with a theatrical event; however, they did not mention any elements beyond our model. In part, the transcriptions of these interviews were used for the wording of the items in the questionnaire. Second, we content analysed 30 reviews of professional theatre performances in 2006 to identify the criteria used by critics in evaluating a theatrical event (cf. Boerner et al., 2008). These reviews have been randomly chosen from the feuilleton sections of three leading German newspapers. As a result, some additional elements of theatregoing could be identified (e.g. the dramatic advisor's contribution to the production, the communication between performers and audience, technical aspects of the staging). Third, including these aspects, a first version of the questionnaire was developed and discussed with theatre professionals (a dramatic advisor and a stage director) before being applied in the field.

The final questionnaire included scales for the overall judgement (three items), the topic of the play (four items), stage direction (seven items), the ensemble (five items), the principal performer (seven items), stage design (eight items), service quality (nine items), respondents' emotional reaction (eight items), and respondents' identification with principal performer (three items). In order to avoid confusion, respondents were asked to consider exclusively the part of Olivia as principal performer. The measurement of these constructs is described in Table $1 .{ }^{1}$

According to Voss and Cova (2006) and to comparable studies on audience experience in opera (Boerner \& Renz, 2008; Boerner et al., 2008; Jobst, 2007), we used 5-point Likert scales ('totally agree, rather agree, neutral, rather not agree, and not agree'). Since this questionnaire was self-designed and used for the first time, we did not know if our questionnaire would correspond to the internal marking schemes that spectators apply in their evaluation of theatre events (cf. Thompson \& Williamon, 2003, p. 35). In the case of respondent uncertainty, arbitrary answers could have resulted (Sirgy et al., 1997). Similar to previous studies on audience experience in opera (Boerner \& Jobst, 2008; Boerner \& Renz, 2008; Boerner et al., 2008; Jobst, 2007), we therefore included the response option I am not able to answer for all scales except the overall judgement, service quality, emotions, and identification. Fortunately, less than $5 \%$ of the respondents on average made use of this option. Nonetheless, we imputed these missing values prior to the main data analyses using the expectation-maximization (EM) algorithm. While being one of the recommended methods for preventing biases caused by not completely random missing data (Allison, 2001; Schafer \& Graham, 2002), the EM algorithm estimates 
Table 1. Questionnaire for visitors' satisfaction with the theatrical event: constructs and items.

\begin{tabular}{ll}
\hline Constructs (number of items) & \multicolumn{1}{c}{ Items } \\
\hline Overall judgement (3) & The evening in theatre was an amazing experience for me \\
Overall, I was disappointed with tonight's evening in theatre & In my mind, this evening will leave a positive memory for a \\
long time & I am interested in the topic of this play \\
The conflicts addressed in this production offered thought- \\
provoking impulses to me \\
In my opinion, this production's topic is quite up-to-date \\
Despite its origin in an early epoch, the play thematically did \\
not become less important \\
I think the stage director has delivered an outstanding \\
performance in this production \\
The production brought this play's message to a head \\
The play's plot was clearly traceable due to the scenic \\
transformation \\
The stage director's concept was coherent \\
I liked this performance's tempo \\
The changeovers from one act to another worked very well \\
Overall, I liked the stage director's composition of the \\
figures
\end{tabular}

The ensemble (5)

The principal performer (7)

Stage design (8)
The whole ensemble interacted very well with respect to their parts

The supporting actors were staffed extremely well

The ensemble had difficulties in coordinating its interaction ${ }^{\mathrm{R}}$

The performing quality of the whole ensemble was considerable

The ensemble distinguished itself by a coherent interaction

The actress represented Olivia's part very convincingly

Her presentation was not authentic for $\mathrm{me}^{\mathrm{R}}$

She passed her part with flying colours

Overall, the actress performed badly ${ }^{R}$

The actress appeared nervous and insecure in her part ${ }^{R}$

The actress articulated very clearly

Due to her facial expression and gesture, the actress happened to express Olivia's part very well

Overall, the stage design (including costumes and requisites) was successful

Overall, the stage design (including costumes and requisites) established keen and coherent pictures

Overall, the stage design was in line with the production's message

I did not like the stage design ${ }^{\mathrm{R}}$

Overall, stage design, costumes, requisites, and light created a coherent atmosphere

The light emphasized particular moments of the production in an exceptional way

The light intensified the stage design's effect

I did not like the costumes at all ${ }^{R}$ 
Table 1. Continued.

\begin{tabular}{|c|c|}
\hline Constructs (number of items) & Items \\
\hline Service Quality (9) & $\begin{array}{l}\text { I was able to find my seat quickly } \\
\text { My seat was comfortable } \\
\text { The auditorium was appropriately tempered } \\
\text { The auditorium had very good acoustics } \\
\text { I was satisfied with the view on the stage that I had from my seat } \\
\text { During the performance there were annoying distractions } \\
\text { (noises, etc.) } \\
\text { Overall, I was comfortable with the catering service } \\
\text { Overall, I was comfortable with the theatre's box office } \\
\text { personal } \\
\text { It was easy to buy tonight's tickets }\end{array}$ \\
\hline Emotional reaction (8) & $\begin{array}{l}\text { I was deeply moved by the performance } \\
\text { The actors left me cold, since there did not appear any crinkly } \\
\text { tenseness between us } \\
\text { Due to the special atmosphere during the performance, I am } \\
\text { emotionally hooked } \\
\text { This performance was literally taking my breath away } \\
\text { In my opinion, this performance will leave a positive memory } \\
\text { for a long time due to its emotional tenseness } \\
\text { I did not feel emotionally addressed by the performance }{ }^{\mathrm{R}} \\
\text { During the performance, time spun away } \\
\text { Overall, I was pretty troubled by the performance }\end{array}$ \\
\hline $\begin{array}{l}\text { Identification with principal } \\
\text { performer (3) }\end{array}$ & $\begin{array}{l}\text { During the performance, I shared excitement with the two } \\
\text { couples } \\
\text { I very much identified with Olivia's part } \\
\text { Occasionally, there was a special emotional relationship } \\
\text { between Olivia and me }\end{array}$ \\
\hline
\end{tabular}

Note: ${ }^{\mathrm{R}}$, polarity reversed.

missing data using an iterative maximum-likelihood procedure (Zwingmann, Wirtz, Müller, Körber, \& Murken, 2006). The imputation was conducted with the software NORM (Graham, Cumsille, \& Elek-Fisk, 2003).

In addition, we offered respondents the opportunity to describe additional aspects of the performance they considered relevant, asking, 'In the case we did not cover everything you consider relevant for the evaluation of the performance, (a) what did you particularly like in this performance?, (b) what did you particularly dislike in this performance?' (cf. Bourgeon as cited in Kotler \& Scheff, 1997). However, the analysis of this section of the questionnaire did not reveal additional elements of spectators' satisfaction. Respondents rather commented on items in the questionnaire, further illustrating their impressions and evaluations.

To measure respondents' levels of experience in theatre, we asked for both the respondents' theatre know-how (layperson, somewhat knowledgeable, regular theatregoer, expert) and the frequency of their attending theatre performances during the previous year. The two items were added to an index, indicating levels of experience in theatre (cf. Kotler \& Scheff, 1997). In order to distinguish between experienced and less experienced attenders, we divided the sample by the mean of the scale, resulting in two sub-samples, which is referred to in the remainder of the paper as experts $(n=75)$ and non-experts $(n=83)$. Demographic variables (age, gender, and general education) and the day of the performance (Friday, Saturday, or Sunday) were asked for as control variables. 


\section{Results \\ Preliminary analyses}

Analyses of internal homogeneity showed acceptable results, Cronbach's $\alpha$ for all scales lying above 0.70 (Table 2), meeting the criterion suggested by Nunnally (1978). Since the scale for service quality consists of very heterogeneous items (e.g. seating comfort, temperature, acoustics, visibility of the stage, disturbing noise, catering, box office personal, ticket purchase), it was designed as a formative measure and included as an index (cf. Homburg \& Klarmann, 2006; Jarvis, MacKenzie, Podsakoff, Mick, \& Bearden, 2003; MacKenzie, Podsakoff, \& Jarvis, 2005).

In accordance with Kline (2005), confirmatory factor analyses (CFA) were run with AMOS 16.0 (Arbuckle \& Wothke, 2003) in order to assess measurement validity. In Model 1, we included all 54 scale items as respective indicators of the underlying eight latent constructs (i.e. overall judgement, the topic of the play, stage direction, the ensemble, the principal performer, stage design, attenders' emotional reaction, and attenders' identification with the principal performer). However, according to global-fit measures, this model showed only poor agreement with the empirical data (Table 3 ). The $\chi^{2}$ value revealed significant differences between the empirical and the model-implied covariances. In addition, the fit index CFI as well as the incremental fit indices NFI and TLI fell below the threshold of 0.90 . Therefore, items with insufficient model compatibility were gradually eliminated from the model (cf. Hair, Anderson, Tatham, \& Black, 2004).

The resulting model (Model 2) included 29 items and reached a good global data fit (Table 3). Moreover, measures of local fit demonstrated that each latent construct was reliably measured by the assigned items. All factor loadings were significant and for every manifest item, more than $30 \%$ of its information was predicted by the underlying construct, i.e. the indicator reliability exceeded 0.3 (for thresholds of acceptable fit, see Bagozzi \& Baumgartner, 1994; Hair et al., 2004). Furthermore, both the factor reliabilities and the average proportions of indicator variance extracted by the corresponding latent construct went beyond the critical values.

Table 2. Intercorrelations between the constructs and reliabilities (Cronbach's $\alpha$ ).

\begin{tabular}{|c|c|c|c|c|c|c|c|c|c|}
\hline & 1 & 2 & 3 & 4 & 5 & 6 & 7 & 8 & 9 \\
\hline Overall judgement & $(0.89)$ & & & & & & & & \\
\hline The topic of the play & $0.33^{* *}$ & $(0.81)$ & & & & & & & \\
\hline Stage direction & $0.82^{* *}$ & $0.34^{* *}$ & $(0.90)$ & & & & & & \\
\hline The ensemble & $0.69^{* * *}$ & $0.21^{* *}$ & $0.79^{* * *}$ & $(0.90)$ & & & & & \\
\hline $\begin{array}{l}\text { The principal } \\
\text { performer }\end{array}$ & $0.50^{* *}$ & $0.28^{* *}$ & $0.55^{* * *}$ & $0.55^{* *}$ & $(0.90)$ & & & & \\
\hline Stage design & $0.48^{* *}$ & $0.19^{*}$ & $0.60^{* * *}$ & $0.43^{* *}$ & $0.28^{* *}$ & $(0.94)$ & & & \\
\hline Service quality & 0.11 & 0.06 & 0.13 & $0.17^{*}$ & 0.09 & 0.07 & $\dagger$ & & \\
\hline $\begin{array}{l}\text { Attenders' emotional } \\
\text { reaction }\end{array}$ & $0.78^{* *}$ & $0.46^{* *}$ & $0.77^{* *}$ & $0.66^{* *}$ & $0.51^{* *}$ & $0.49^{* *}$ & 0.12 & $(0.91)$ & \\
\hline $\begin{array}{l}\text { Attenders' } \\
\text { identification }\end{array}$ & $0.43^{* *}$ & $0.36^{* *}$ & $0.44^{* *}$ & $0.40^{* *}$ & $0.49^{* *}$ & $0.30^{* *}$ & 0.07 & $0.63^{* *}$ & $(0.79)$ \\
\hline
\end{tabular}

Note: Reliabilities (Cronbach's $\alpha$ ) are shown in italics on the diagonal. Due to the missing of musical elements of the observed performance, no music scale was measured and is therefore not listed here.

This scale was designed as a formative measure and included as an index (Homburg \& Klarmann, 2006; Jarvis et al., 2003; MacKenzie et al., 2005).

${ }^{*} p \leq 0.05$.

${ }^{* *} p \leq 0.01$. 
Table 3. Measures of global fit for the models estimated (CFA).

\begin{tabular}{rrrcccccc}
\hline & $\chi^{2}$ & $d f$ & $p$ & $\chi^{2} / d f$ & NFI & TLI & CFI & RMSEA \\
\hline Model 1 & 1870.90 & 874 & 0.000 & 2.14 & 0.74 & 0.83 & 0.84 & 0.084 \\
Model 2 & 657.14 & 349 & 0.000 & 1.88 & 0.85 & 0.91 & 0.92 & 0.074 \\
\hline
\end{tabular}

Note: NFI, normed fit index; TLI, Tucker-Lewis index; CFI, comparative fit index; RMSEA, root mean square error of approximation.

In order to ensure discriminant validity of the determinants of visitors' satisfaction with the theatrical event, we eventually conducted CFA for different models. We compared an eight-factor model containing the overall judgement, stage direction, the topic of the play, stage design, the ensemble, the principal performer, emotional reaction, and identification with the principal performer as separate factors to various alternative models. As expected, we found the eight-factor model to show a considerably better fit than the alternatives (Table 4).

\section{Analysing the determinants of visitors' satisfaction with the theatrical event}

In a hierarchical regression analysis, spectators' satisfaction with the evening was regressed on the controls (Model 1) and all the determinants included in Figure 1 (Model 2, Table 5). The resulting model (Model 2) explained $72 \%$ of the variance in spectators' satisfaction. None of the control variables reached significance. The far most relevant determinant for spectators' satisfaction with the evening was their judgements on the stage direction $(\beta=0.51, p<0.000)$, followed by their emotional reaction $(\beta=0.39, p<0.000)$. However, none of the other determinants in the model (Figure 1) turned out to be significant.

\section{Analysing differences between experts and non-experts}

First, respondents' level of experience did not turn out to be a significant control variable (Table 5), indicating no significant differences in experts' and non-experts' levels of satisfaction with the evening. Similarly, $t$-tests did not reveal any significant difference between experts' and non-experts' evaluation of the evening.

The assumption that non-experts would differ from experts in the weight they give to individual determinants of their satisfaction in theatre could have been tested by analysing interaction effects. However, since experience did not reach significance as a control variable (see above), no main effects of 'the satisfaction experience in the theatre' variable could be confirmed. Hence, it was not adequate to test for any interaction effects (Afifi, Clark, \& May, 2004).

Table 4. Measures of global fit for the models estimated (CFA).

\begin{tabular}{lrccccccc}
\hline & $\chi^{2}$ & $d f$ & $p$ & $\chi^{2} / d f$ & NFI & TLI & CFI & RMSEA \\
\hline 1-Factor Model & 1964.40 & 377 & 0.000 & 5.21 & 0.56 & 0.57 & 0.60 & 0.162 \\
2-Factor Model & 1818.46 & 376 & 0.000 & 4.84 & 0.59 & 0.61 & 0.64 & 0.154 \\
3-Factor Model & 1656.03 & 374 & 0.000 & 4.43 & 0.63 & 0.65 & 0.68 & 0.146 \\
4-Factor Model & 1512.66 & 371 & 0.000 & 4.08 & 0.66 & 0.69 & 0.72 & 0.138 \\
8-Factor Model & 657.14 & 349 & 0.000 & 1.88 & 0.85 & 0.91 & 0.92 & 0.074 \\
\hline
\end{tabular}

Note: NFI, normed fit index; TLI, Tucker-Lewis index; CFI, comparative fit index; RMSEA, root mean square error of approximation. 
Table 5. Multiple regression analysis. Dependent variable: Visitors' satisfaction with the theatrical event.

\begin{tabular}{lcc}
\hline & Model 1 & Model 2 \\
\hline Step and variable & & \\
Model 1 & 0.1 & 0.02 \\
Sex & 0.11 & -0.06 \\
Age & 0.04 & 0.01 \\
Education & -0.08 & -0.06 \\
Expertise & 0.05 & 0.01 \\
Day of the performance & & \\
Model 2 & & $0.51^{* * *}$ \\
Stage direction & & $0.39^{* * *}$ \\
Emotional reaction & & -0.03 \\
Topic of the play & & 0.07 \\
Ensemble & & 0.04 \\
Principal performer & & -0.04 \\
Stage design & & 0.01 \\
Service quality & 0.004 & -0.04 \\
Identification & & $0.717^{* * *}$ \\
Adjusted- $R^{2}$ &
\end{tabular}

Note: $n=158$. Standardized regression coefficients are reported.

*** $p<0.00$.

Second, to determine the degree of agreement among experts and among non-experts, we calculated the intra-class correlation coefficients $\mathrm{ICC}_{\text {unjust }}$ (Commenges \& Jacqmin, 1994; Wirtz \& Caspar, 2002) for each group. Since all the judgements should refer to the same event, we calculated the coefficients separately for each performance. However, regardless of the day of the performance, experts highly agreed on their satisfaction with the event and all its determinants, except service quality (Table 6). ${ }^{2}$ In contrast, non-experts did not agree on the identification with the principle performer, the topic of the play, and the service quality (Table 6).

Table 6. Inter-rater agreement (ICC $\left.\mathrm{Injust}_{\mathrm{j}}\right)$.

\begin{tabular}{|c|c|c|c|c|c|c|}
\hline \multirow[b]{2}{*}{ Scale } & \multicolumn{2}{|c|}{ Friday } & \multicolumn{2}{|c|}{ Saturday } & \multicolumn{2}{|c|}{ Sunday } \\
\hline & $\begin{array}{l}\text { Experts } \\
(n=32)\end{array}$ & $\begin{array}{c}\text { Non- } \\
\text { experts } \\
(n=33)\end{array}$ & $\begin{array}{l}\text { Experts } \\
(n=17)\end{array}$ & $\begin{array}{c}\text { Non- } \\
\text { experts } \\
(n=18)\end{array}$ & $\begin{array}{l}\text { Experts } \\
(n=26)\end{array}$ & $\begin{array}{c}\text { Non- } \\
\text { experts } \\
(n=32)\end{array}$ \\
\hline Overall judgement & $0.846^{* * * *}$ & $0.882^{* * *}$ & 0.088 & $0.843^{* * *}$ & $0.852^{* * *}$ & $0.827^{* * *}$ \\
\hline The topic of the play & $0.716^{* * *}$ & $0.524^{* *}$ & $0.847^{* * *}$ & $0.768^{* * *}$ & $0.829^{* * *}$ & $0.727^{* * * *}$ \\
\hline Stage direction & $0.872^{* * * *}$ & $0.904^{* * *}$ & $0.868^{* * * *}$ & $0.909^{* * *}$ & $0.898^{* * * *}$ & $0.886^{* * * *}$ \\
\hline The ensemble & $0.915^{* * *}$ & $0.859^{* * *}$ & $0.803^{* * *}$ & $0.895^{* * *}$ & $0.940^{* * *}$ & $0.910^{* * *}$ \\
\hline The principal performer & $0.850^{* * *}$ & $0.843^{* * *}$ & $0.910^{* * *}$ & $0.881^{* * *}$ & $0.889^{* * *}$ & $0.880^{* * *}$ \\
\hline Stage design & $0.937^{* * *}$ & $0.930^{* * *}$ & $0.972^{* * *}$ & $0.965^{* * *}$ & $0.855^{* * * *}$ & $0.931^{* * *}$ \\
\hline Service quality & -0.167 & 0.025 & -0.819 & -0.271 & 0.090 & -0.493 \\
\hline $\begin{array}{l}\text { Attenders' emotional } \\
\text { reaction }\end{array}$ & $0.903^{* * * *}$ & $0.891^{* * * *}$ & $0.887^{* * * * *}$ & $0.895^{* * *}$ & $0.921^{* * * * *}$ & $0.904^{* * *}$ \\
\hline Attenders' identification & $0.841^{* * *}$ & $0.650^{* * *}$ & $0.798^{* * *}$ & $0.760^{* * *}$ & $0.845^{* * *}$ & $0.478^{* * *}$ \\
\hline
\end{tabular}

${ }^{* *} p<0.01$

${ }^{* * *} p<0.000$. 


\section{Discussion}

\section{Summary}

Research on post-performance audience reception in theatre is frequently called for, but still scarce. The aim of this paper was thus to investigate spectators' satisfaction with a theatrical event. Building on both research in theatre marketing and theatre studies, we suggested a model explaining visitors' satisfaction in theatre. In this model, we assumed aspects of the core quality (i.e. the topic of the play, stage direction, the ensemble, the principal performer, stage design, music), the service quality (infrastructure and service), attenders' emotional reaction, and attenders' identification with the principal performer to be determinants of visitors' satisfaction in theatre.

A field study $(n=158)$ in a German community theatre performing Shakespeare's Twelfth Night or What You Will was conducted addressing two questions. (1) What are the determinants of visitors' satisfaction with a theatrical event? (2) Does visitors' satisfaction with an event differ according to their level of experience? First, only spectators' judgements on stage direction and their emotional reaction to the performance turned out to be significant determinants of their satisfaction with the evening. Nevertheless, these two determinants account for the major part (72\%) of the variance of visitors' satisfaction in theatre. Compared with similar studies, this amount is fairly high (e.g. Garbarino \& Johnson, 2001). In our study, visitors' satisfaction thus seems not to result from a systematic analysis of the individual elements of a theatrical event (e.g. the actors, the play), but from an overall judgement on the interpretation of a given play. Concerning the spectators' emotional reaction to the performance, our study confirms the findings by Eversmann (2004) as well as findings in the context of opera (Behr, 1983; Jobst, 2007). Unlike the findings by Garbarino and Johnson (2001), the service quality (infrastructure and service) was not confirmed as a significant determinant of theatregoers' satisfaction. However, this result is in line with findings from Wakefield and Blodgett (1999, p. 52), suggesting 'that the tangible physical environment is relatively unimportant'.

Second, contrary to our expectations, only minor differences were found between more and less experienced theatregoers as measured in our study. Visitors' level of expertise did neither affect their judgements on the individual determinants of their overall satisfaction nor their overall level of satisfaction. Likewise, the results of our study did not indicate that non-experts differ from experts in the weight they give to individual determinants of their satisfaction. Similarly, the notion that experienced theatregoers would produce more homogeneous judgements than inexperienced attendees could not be confirmed. Regarding the overall satisfaction and most of its determinants, there was equally high agreement among experts and non-experts of our sample. The only difference between experts and non-experts was that non-experts tended not to agree on their identification with the principle performer (see Friday, Saturday, and Sunday samples) and on the topic of the play (see Friday sample), whereas experts did. Although individual factors like personal, demographic, or psychographic factors are likely to result in differences in spectators' subjective judgements, the attenders of Twelfth Night or What You Will agreed on almost all aspects of the evening.

\section{Limitations}

First, since we were not able to hark back to established measures, scales for measuring spectators' satisfaction with a theatrical event and its determinants had to be developed for the purpose of this study. Since these measures have not been validated in a separate sample, the results of this study have to be interpreted very carefully. However, probably 
due to the extensive efforts undertaken in designing the questionnaire, the first application in the field achieved sufficient discriminant validity and reliability for all scales. Further attempts in reception research may thus use this questionnaire as a starting point.

Second, our results are based on only three performances of the production Twelfth Night or What You Will at Konstanz-Theatre. Thus, our results cannot be generalized to assessment in theatre. Regarding differences between experienced and inexperienced attenders, our findings are similar to prior results in opera (Boerner \& Renz, 2008; Jobst, 2007). Still, to allow for sound conclusions and recommendations, additional field studies in theatre are required in order to obtain more data. Such studies would have to systematically control for the genre of the presented work (e.g. modern versus traditional play), the type of event (e.g. matinee, première, regular performance), the style of production (conventional versus modern or avant-garde), and the reputation of the theatre company under study.

\section{Implications for theatre marketing}

If further research will confirm our findings, the following implications for theatre marketing can be drawn. First, our results suggest that subjective judgements on a theatrical event can be equally obtained from either experienced or inexperienced attenders. In order to investigate theatregoers' satisfaction, thus either experts or non-experts can be involved.

Second, performance indicators in theatre usually are reported as statistics, ratios, costs, or other ways of measuring a theatre's progress in achieving its aims (Gilhespy, 1999; Glejser \& Heyndels, 2001; Senior, 2004). However, these indicators do not tend to include reference to the quality of the visitor experience. Against this background, our study contributed to explore visitor outcomes (Soren, 2000), i.e. what are the benefits, changes, effects, or consequences for a visitor after attending a theatrical event. Probably the most surprising result of our study is the fact that the service quality (i.e. infrastructure and service) was not confirmed to be a significant determinant of theatregoers' overall satisfaction. Existing literature expected the service quality provided by the theatre company to contribute considerably to visitors' overall satisfaction - complementing the performance itself (Günter, 2001; Haefs \& Schmidt, 1999; Hausmann, 2007). If the results of our study will hold true in further studies, traditional efforts in theatre marketing (DiMaggio, 1987; Kotler \& Scheff, 1997; Sargeant, 1997; Senior, 2004) seem to focus on issues of minor relevance to spectators' satisfaction in theatre. The results of our study indicate that emotional reactions were a very important determinant of theatregoers' satisfaction. Efforts to further analyse the emotions aroused in live performances may thus serve as point of departure for audience development. As Scollen (2008) demonstrated, theatres' endeavours to understand their target markets and to discover how they experience their product can enhance ticket purchases.

\section{Conclusions}

To sum up, we see the main contribution of our paper to the extant body of literature in theatre marketing in the following points: first, our model is able to explain a considerable portion (i.e. $72 \%$ ) of the variance in visitors' satisfaction in theatre. Thus, to the best of our knowledge, for the first time in the literature, the major part of customer satisfaction in theatre has been explained. Nevertheless, further elaborations of the model should include and test additional variables like, for example, personal antecedents such as 
visitors' motives and expectations (e.g. the need for social recognition or social distinction; Bourdieu, 1984).

Second, based on the extant literature on theatre marketing and theatre studies, one would expect the determinants included in the model to be more or less equally relevant. However, given the results of our study, this expectation needs revision. Reviewing the extant literature, we did not find a paper predicting these outcomes of our study. In particular, the literature on theatre marketing is contradictory about the relevance of the service quality for visitors' satisfaction in theatre (cf. Garbarino \& Johnson, 2001; Wakefield \& Blodgett, 1999). The results of our study, indicating that the service quality is not relevant for visitors' satisfaction in theatre, may directly contribute to this controversy. The same holds true for the controversial discussion about possible differences between experts and non-experts (pp. 4-6).

Third, our study is the first to provide and test an instrument to capture visitors' satisfaction in theatre and its possible determinants. We therefore see the particular contribution of our paper not only in the results discussed above, but in the first step towards the development of a valid and reliable instrument. Of course, the first version of this instrument is not perfect. However, it may serve as a starting point for further research on the topic.

\section{Notes}

1. Since there was no music in the production of Twelfth Night or What You Will, this element was not considered in our study.

2. A sufficiently high inter-rater agreement is assumed if $\mathrm{ICC}_{\text {unjust }}=0.70$ is met (Wirtz \& Caspar, 2002).

\section{References}

Abbé-Decarroux, F. (1994). The perception of quality and the demand for services. Empirical application to the performing arts. Journal of Economic Behaviour and Organization, 23(1), 99-107.

Adorno, T.W. (1962). Einleitung in die musiksoziologie. Frankfurt, Germany: Suhrkamp.

Afifi, A., Clark, V.A., \& May, S. (2004). Computer-aided multivariate analysis. Boca Raton, FL: Chapman \& Hall/CRC.

Allison, P.D. (2001). Missing data. Thousand Oaks, FL: Sage.

Andringa, E. (2004). The interface between fiction and life: Patterns of identification in reading autobiographies. Poetics Today, 25(2), 205-240.

Arbuckle, J.L., \& Wothke, W. (2003). AMOS 4.0 user's guide. Chicago: Small-Waters Corporation.

Asch, S.E. (1956). Studies of independence and conformity: A minority of one against a unanimous majority. Psychological Monographs, 70(9), 221-240.

Auvinen, T. (2001). Why is it difficult to manage an opera house? The artistic-economic dichotomy and its manifestations in the organizational structures of five opera organizations. Journal of Arts Management, Law, and Society, 30(4), 268-282.

Bagozzi, R., \& Baumgartner, H. (1994). The evaluation of structural equation models and hypothesis testing. In R. Bagozzi (Ed.), Principles of marketing research (pp. 386-422). Cambridge, MA: Blackwell.

Behne, K. (1997). Musikästhetik. III. Musikalische urteilsbildung. In L. Finscher (Ed.), Die musik in geschichte und gegenwart (pp. 998-1016). Kassel, Germany: Bärenreiter/Metzler.

Behr, M. (1983). Musiktheatre - Faszination, wirkung, funktion. Wilhelmshaven, Germany: Heinrichshofen.

Berlyne, D. (1971). Aesthetics and psychobiology. New York: Appleton-Century-Crofts.

Boerner, S. (2002). Führungsverhalten und führungserfolg - Beitrag zu einer theorie der führung am beispiel des musiktheatres. Wiesbaden, Germany: Gabler. 
Boerner, S., \& Jobst, J. (2008). The perception of artistic quality in opera - results from a field study. Journal of New Music Research, 37(3), 233-245.

Boerner, S., Neuhoff, H., Renz, S., \& Moser, V. (2008). Evaluation in music theatre: Empirical results on content and structure of the audience's quality judgment. Empirical Studies of the Arts, 26(1), 15-35.

Boerner, S., \& Renz, S. (2008). Performance measurement in opera companies - comparing subjective quality judgments of experts and non-experts. International Journal of Arts Management, 10(3), 21-37.

Boorsma, M., \& van Maanen, H. (2003). View and review in the Netherlands: The role of theatre critics in the construction of audience experience. International Journal of Cultural Policy, 9(3), 319-335.

Bourdieu, P. (1984). Distinction: A social critique of the judgment of taste. Boston: Harvard University Press.

Bourdieu, P. (1993). The field of cultural production. New York: Columbia University Press.

Broadbent, D.E. (1964). Perception and communication. Oxford, UK: Pergamon.

Caust, J. (2003). Putting the 'art' back into arts policy making: How arts policy has been 'captured' by the economists and the marketers. The International Journal of Cultural Policy, 9(1), $51-63$.

Commenges, D., \& Jacqmin, H. (1994). The intraclass correlation coefficient: Distribution-free definition and test. Biometrics, 50(2), 517-526.

Cronin, J.J., Brady, M., \& Hult, G. (2000). Assessing the effects of quality, value, and customer satisfaction on consumer behavioural intentions in service environments. Journal of Retailing, $76(2), 193-218$.

Cronin, J.J., \& Taylor, S.A. (1992). Measuring service quality: A reexamination and extension. Journal of Marketing, 56(7), 55-68.

Crozier, R. (1996). Music and social influence. In A.C. North \& D.J. Hargreaves (Eds.), The social psychology of music (pp. 67-83). UK: Oxford University Press.

Dabholkar, P., Shepherd, C.D., \& Thorpe, D.I. (2000). A comprehensive framework for service quality: An investigation of critical conceptual and measurement issues through a longitudinal study. Journal of Retailing, 76(2), 139-173.

DiMaggio, P. (1987). Nonprofit organizations in the production and distribution of culture. In W.W. Powell (Ed.), The nonprofit sector. A research handbook (pp. 195-220). New Haven, CT: Yale University Press.

DiMaggio, P., Useem, M., \& Brown, P. (1978). Audience studies of the performing arts and museums: A critical review. Washington, DC: National Endowment for the Arts.

Eikhof, D.R., \& Haunschild, A. (2007). For art's sake! Artistic and economic logics in creative production. Journal of Organizational Behaviour, 28(5), 523-538.

Eversmann, P. (2004). The experience of the theatrical event. In V.A. Cremona, P. Eversmann, H. van Maanen, W. Sauter, \& J. Tulloch (Eds.), Theatrical events - borders dynamics frames (pp. 139-174). Amsterdam: Rodopi.

Gainer, B., \& Padanyi, P. (2002). Applying the marketing concept to cultural organisations: An empirical study of the relationship between market orientation and performance. International Journal of Nonprofit and Voluntary Sector Marketing, 7(2), 182-193.

Garbarino, E., \& Johnson, M.S. (2001). Effects of consumer goals on attribute weighting, overall satisfaction, and product usage. Psychology and Marketing, 18(9), 929-949.

Gilhespy, I. (1999). Measuring the performance of cultural organizations: A model. International Journal of Arts Management, 2(1), 38-52.

Glejser, H., \& Heyndels, B. (2001). Efficiency and inefficiency in the ranking in competitions: The case of the Queen Elisabeth music contest. Journal of Cultural Economic, 25(2), 109-129.

Graham, J.W., Cumsille, P.E., \& Elek-Fisk, E. (2003). Methods for handling missing data. In J.A. Schinka \& W.F. Velicer (Eds.), Research methods in psychology (pp. 87-114). New York: Wiley.

Grönroos, C. (1984). A service quality model and its marketing implications. European Journal of Marketing, 18(4), 36-44.

Günter, B. (2001). Kulturmarketing. In D.K. Tscheulin \& B. Helmig (Eds.), Branchenspezifisches marketing. Grundlagen, besonderheiten, gemeinsamkeiten (pp. 331-349). Wiesbaden, Germany: Gabler. 
Haefs, S., \& Schmidt, K. (1999). Wirkungsvolle Strukturen im Kulturbereich. Ergebnisse des Servicetests an 15 deutschen Theatren. Gütersloh, Germany: Verlag Bertelsmann Stiftung.

Hair, J.F., Anderson, R.E., Tatham, R.L., \& Black, W.C. (2004). Multivariate data analysis. Upper Saddle River, NJ: Prentice Hall.

Hausmann, A. (2007). Das publikum von morgen. herausforderungen des demographischen wandels für kulturbetriebe. Kulturpolitische Mitteilungen, 117(2), 54-57.

Holbrook, M.B. (1999). Popular appeal versus expert judgment of motion pictures. Journal of Consumer Research, 26(2), 144-155.

Holbrook, M.B. (2005). The role of ordinary evaluations in the market for popular culture: Do consumers have 'good taste'? Marketing Letters, 16(2), 75-86.

Holbrook, M.B., Lacher, K.T., \& La Tour, M.S. (2006). Audience judgments as the potential missing link between expert judgments and audience appeal: An illustration based on musical recordings of 'my funny valentine'. Journal of the Academy of Marketing Science, 34(1), 8-18.

Homburg, C., \& Klarmann, M. (2006). Die kausalanalyse in der empirischen betriebswirtschaftlichen forschung - problemfelder und anwendungsempfehlungen. Die Betriebswirtschaft, 66(6), 727-748

Jarvis, C., MacKenzie, S., Podsakoff, P.M., Mick, D.G., \& Bearden, W.O. (2003). A critical review of construct indicators and measurement model misspecification in marketing and consumer research. Journal of Consumer Research, 30(2), 199-218.

Jobst, J.M. (2007). Evaluation in öffentlichen dienstleistungsunternehmen. Eine empirische untersuchung zur entstehung des publikumsurteils im musiktheatre. Masters thesis, Konstanz University, Germany.

Joyce, W.F., \& Slocum, J.W. (1990). Strategic context and organizational climate. In B. Schneider (Ed.), Organizational climate and culture (pp. 130-150). San Francisco, CA: Jossey-Bass.

Kline, R.B. (2005). Principles and practice of structural equation modelling. New York: Guilford Press.

Konijn, E.A. (1991). What's on between the actor and his audience? Empirical analysis of emotion processes in the theatre. In G.D. Wilson (Ed.), Psychology and performing arts (pp. 59-75). Amsterdam: Swets \& Zeitlinger.

Konijn, E.A. (1999). Spotlight on spectators: Emotions in the theatre. Discourse Processes, 28(2), $169-194$.

Kotler, R., \& Scheff, J. (1997). Standing room only. Strategies for marketing the performing arts. Boston: Harvard Business School Press.

Lewis, R., \& Booms, B. (1983). The marketing aspects of service quality. In L. Berry, G. Shostack, \& G. Upah (Eds.), Emerging perspectives on services marketing (pp. 99-107). Chicago: American Marketing Association.

List, M. (1997). Qualifikation der kritiker. Alles theatre? Bühne, Öffentlichkeit und die kritik. Münster, Germany: Daedalus.

MacKenzie, S.B., Podsakoff, P.M., \& Jarvis, C. (2005). The problem of measurement model misspecification in behavioural and organizational research and some recommended solutions. Journal of Applied Psychology, 90(4), 710-730.

March, R., \& Thompson, B. (1996). Performing arts marketing in Australia: A study of marketing orientation and marketing planning in the Australian performing arts field. Nepean, Australia: University of Western Sydney.

Martin, J., \& Sauter, W. (1995). Understanding theatre. Stockholm: Almqvist \& Wiksell International.

Nunnally, J.C. (1978). Psychometric theory. New York: McGraw-Hill Book.

Oliver, R. (1996). Satisfaction: A behavioural perspective on the consumer. New York: McGraw Hill.

Parasuraman, A., Zeithaml, V., \& Berry, L. (1988). Servqual: A multiple-item scale for measuring consumer perceptions of service quality. Journal of Retailing, 64(1), 12-40.

Pavis, P. (1988). Semiotik der theatrerezeption. Tübingen, Germany: Narr.

Perky, S.D. (1976). Effects of positive and negative audience response on actor's nonverbal performance behaviour and on their attitudes. Doctoral dissertation, Bowling Green State University, Bowling Green, Ohio.

Rentschler, R., Radbourne, J., Carr, R., \& Rickard, J. (2002). Relationship marketing, audience retention and performing arts organization viability. International Journal of Nonprofit and Voluntary Sector Marketing, 7(2), 118-130. 
Sargeant, A. (1997). Marketing the arts - classification of UK theatre audiences. Journal of Nonprofit \& Public Sector Marketing, 5(1), 45-62.

Sauter, W. (2000). The theatrical event. Iowa City: University of Iowa Press.

Sauter, W. (2002). Who reacts when, how and upon what: From audience surveys to the theatrical event. Contemporary Theatre Review, 12(3), 115-129.

Sauter, W., Kalvik, A., \& Isaksson, C. (1986). Das publikum - Verständnis und erlebnis von theatreaufführungen. In $\mathrm{H}$. Schoenmakers (Ed.), Performance theory - advances in reception and audience research (pp. 83-110). Utrecht, The Netherlands: Institut voor Theatrewetenschap.

Schafer, J.L., \& Graham, J.W. (2002). Missing data: Our view of the state of the art. Psychological Methods, 7(2), 147-177.

Scheff, J., \& Kotler, P. (1996). Crisis in the arts: The marketing response. California Management Review, 39(1), 28-52.

Schoenmakers, H. (1988). To be, wanting to be, forced to be. In W. Sauter (Ed.), Performance theory - advances in reception and audience research (pp. 138-163). Utrecht, The Netherlands: Institut voor Theatrewetenschap.

Schoenmakers, H. (Ed.). (1992). Aesthetic emotions and aetheticised emotions in theatrical situations. Performance theory - advances in reception and audience research (pp. 39-58). Utrecht, The Netherlands: Institut voor Theatrewetenschap.

Schoenmakers, H., \& Tulloch, J. (2004). From audience research to the study of theatrical events: A shift in focus. In V.A. Cremona, P. Eversmann, H. van Maanen, W. Sauter, \& J. Tulloch (Eds.), Theatrical events: Borders dynamics frames (pp. 15-29). Amsterdam: Rodopi.

Schwerdtfeger, D. (2004). Markenpolitik für theatre. Ein produktpolitisches marketingkonzept. Köln, Germany: Fördergesellschaft Produkt-Marketing e.V.

Scollen, R.J. (2008). Regional voices talk theatre: Audience development for the performing arts. International Journal of Nonprofit and Voluntary Sector Marketing, 13(1), 45-56.

Seiders, K., Voss, G., Grewal, D., \& Godfrey, A. (2005). Do satisfied customers buy more? Examining moderating influences in a retailing context. Journal of Marketing, 69(4), 26-43.

Senior, I. (2004). Theatre critics and theatre going. Economic Affairs, 24(2), 65-69.

Shoham, A., Ruvio, A., Vigoda-Gadot, E., \& Schwabsky, N. (2006). Market orientations in the nonprofit and voluntary sector: A meta-analysis of their relationships with organizational performance. Nonprofit and Voluntary Sector Quarterly, 35(3), 453-476.

Sirgy, M.J., Grewal, D., Mangleburg, T., Park, J., Chon, K., Claiborne, C.B., et al. (1997). Assessing the predictive validity of two methods of measuring self-image congruence. Journal of the Academy of Marketing Science, 25(3), 229-241.

Soren, B.J. (2000). The learning cultural organization of the millennium: Performance measures and audience response. International Journal of Arts Management, 2(2), 40-49.

Tan, E. (1994). Film-induced affect as a witness emotion. Poetics, 23(1-2), 7-32.

Tan, E. (1996). Emotion and the narrative structure of film. Mahwah, NJ: Lawrence Erlbaum Association.

Thompson, S. (2006). Audience responses to a live orchestral concert. Musicae Scientiae, 10(2), 215-244.

Thompson, S., \& Williamon, A. (2003). Evaluating evaluation: Musical performance assessment as a research tool. Music Perception, 21(1), 21-41.

Tobias, S. (2004). Quality in the performing arts: Aggregating and rationalizing expert opinion. Journal of Cultural Economics, 28(2), 109-124.

Voss, Z.G., \& Cova, V. (2006). How sex differences in perceptions influence customer satisfaction: A study of theatre audiences. Marketing Theory, 6(2), 201-221.

Voss, G.B., \& Voss, Z.G. (2000). Strategic orientation and firm performance in an artistic environment. Journal of Marketing, 64(1), 67-83.

Wakefield, K.L., \& Blodgett, J.G. (1999). Customer response to intangible and tangible service factors. Psychology \& Marketing, 16(1), 51-68.

Wirtz, M.A., \& Caspar, F. (2002). Beurteilerübereinstimmung und beurteilerreliabilität. methoden zur bestimmung und verbesserung der zuverlässigkeit von einschätzungen mittels kategoriensystemen und ratingskalen. Göttingen, Germany: Hogrefe.

Wirtz, J., \& Lee, M.C. (2003). An examination of the quality and context-specific applicability of commonly used customer satisfaction measures. Journal of Service Research, 5(4), 345-355.

Zeithaml, V.A., Parasuraman, A., \& Berry, L.L. (1996). The behavioural consequences of service quality. Journal of Marketing, 60(2), 31-46. 
Zillmann, D. (1991). Empathy: Affect from bearing witness to the emotions of others. In J. Bryant \& D. Zillmann (Eds.), Responding to the screen: Reception and reaction processes (pp. 135-167). Hillsdale, NJ: Erlbaum.

Zillmann, D. (1995). Mechanisms of emotional involvement with drama. Poetics, 23(1-2), 33-51. Zwingmann, C., Wirtz, M., Müller, C., Körber, J., \& Murken, S. (2006). Positive and negative religious coping in German breast cancer patients. Journal of Behavioural Medicine, 29(6), 533-547. 